\title{
REVIEW \\ The Technology of Phosphorous Removal and Recovery from Swine Wastewater by Struvite Crystallization Reaction
}

\author{
Kazuyoshi SUZUKI*, Yasuo TANAKA, Kazutaka KURODA, \\ Dai HANAJIMA, Yasuyuki FUKUMOTO and Tomoko YASUDA \\ Pollution Control Research Team, National Institute of Livestock and Grassland Science (NILGS) \\ (Tsukuba, Ibaraki 305-0901, Japan)
}

\begin{abstract}
Swine wastewater has a high potential for phosphorous recovery in Japan. The $\mathrm{pH}$ of swine wastewater increased up to approximately 8.5 with continuous aeration, and a large part of the soluble $\mathrm{PO}_{4}$ $\mathrm{P}, \mathrm{Mg}$ and $\mathrm{Ca}$ was crystallized. A reactor for removing and recovering phosphorous from swine wastewater was designed with a dual function i.e., crystallization through aeration, and separation of formed struvite by settling. However, a dehydration, composting and characterization process was first needed before using sediment sludge, including struvite, on farmland, since it will settle along with huge amounts of other suspended solids (organic matter). For the recovery of pure struvite, an accumulation device was designed and its efficiency was examined. During submergence in the aeration column of the demonstration reactor, struvite cross-bridged and it accumulated on the face of the device. The struvite could be scraped off easily with only a light brushing, and was found to be approximately $95 \%$ pure. Because this device is made of a very simple structure, it should be acceptable to swine farmers.
\end{abstract}

Discipline: Animal industry / Agricultural environment

Additional key words: HAP, hydroxyapatite, magnesium ammonium phosphate, MAP

\section{Introduction}

All the phosphate rock Japan needs must currently be imported from abroad, because it has no subterranean phosphorous resources. Recently, the amount of imported phosphate rock has been decreasing because the United States, which accounted for approximately $40 \%$ of Japan's imports in 1990, stopped exporting it in 1995 (Fig. 1). Since this phosphorous shortage has become increasingly serious, we need to accelerate the development and establishment of the technologies for phosphorous recovery from waste and wastewater.

\section{Phosphorous in swine wastewater within Japan}

In many swine husbandry facilities in Japan, the feces, urine and washing water from piggeries are separated into solid and liquid fractions by mechanical solid- liquid separation ${ }^{6}$. The solid fraction is composted and utilized for farmland fertilizer. The law requires the liquid fraction (swine wastewater) to be purified through a treatment process before being discharged into public waters.

In addition to $\mathrm{PO}_{4}{ }^{3-}$ and $\mathrm{NH}_{4}{ }^{+}$, swine wastewater also contains high concentrations of $\mathrm{Mg}^{2+}$ and $\mathrm{Ca}^{2+}{ }^{10,11}$. According to our estimation, approximately 13, 24 and $17 \%$ of given $\mathrm{P}, \mathrm{Mg}$ and $\mathrm{Ca}$ amounts, respectively, were separated into liquid fractions (swine wastewater) following solid-liquid separation, when $30 \%$ of excreted feces became mixed with urine and washing water (Fig. 2). In this case, concentrations of $\mathrm{P}, \mathrm{Mg}$ and $\mathrm{Ca}$ in liquid fractions (swine wastewater) were calculated to be 120 , 63 and $210 \mathrm{mg} / \mathrm{L}$, respectively ${ }^{13}$.

To confirm such high concentrations of $\mathrm{P}, \mathrm{Mg}$ and $\mathrm{Ca}$, swine wastewater from 9 piggeries in Japan was analyzed. The above components were determined according to the standard methods ${ }^{1}$. Crystallized and

*Corresponding author: fax +81-29-838-8606; e-mail szkazu@affrc.go.jp

Received 29 September 2005; accepted 28 December 2005. 


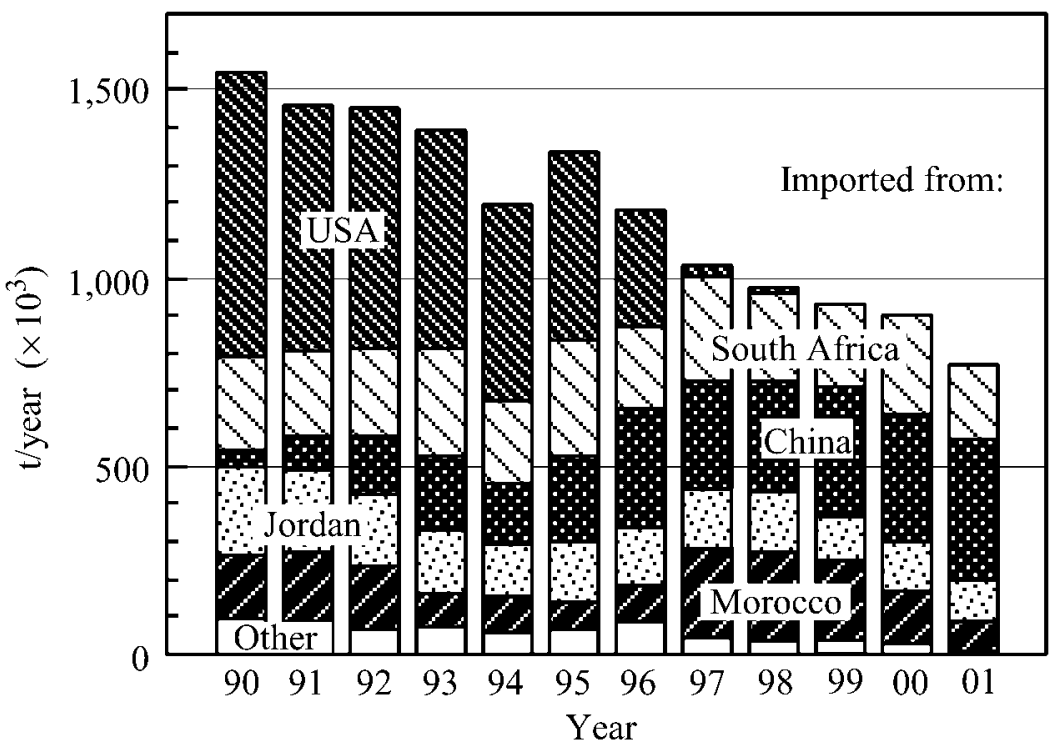

Fig. 1. Change of phosphate rock amount imported into Japan

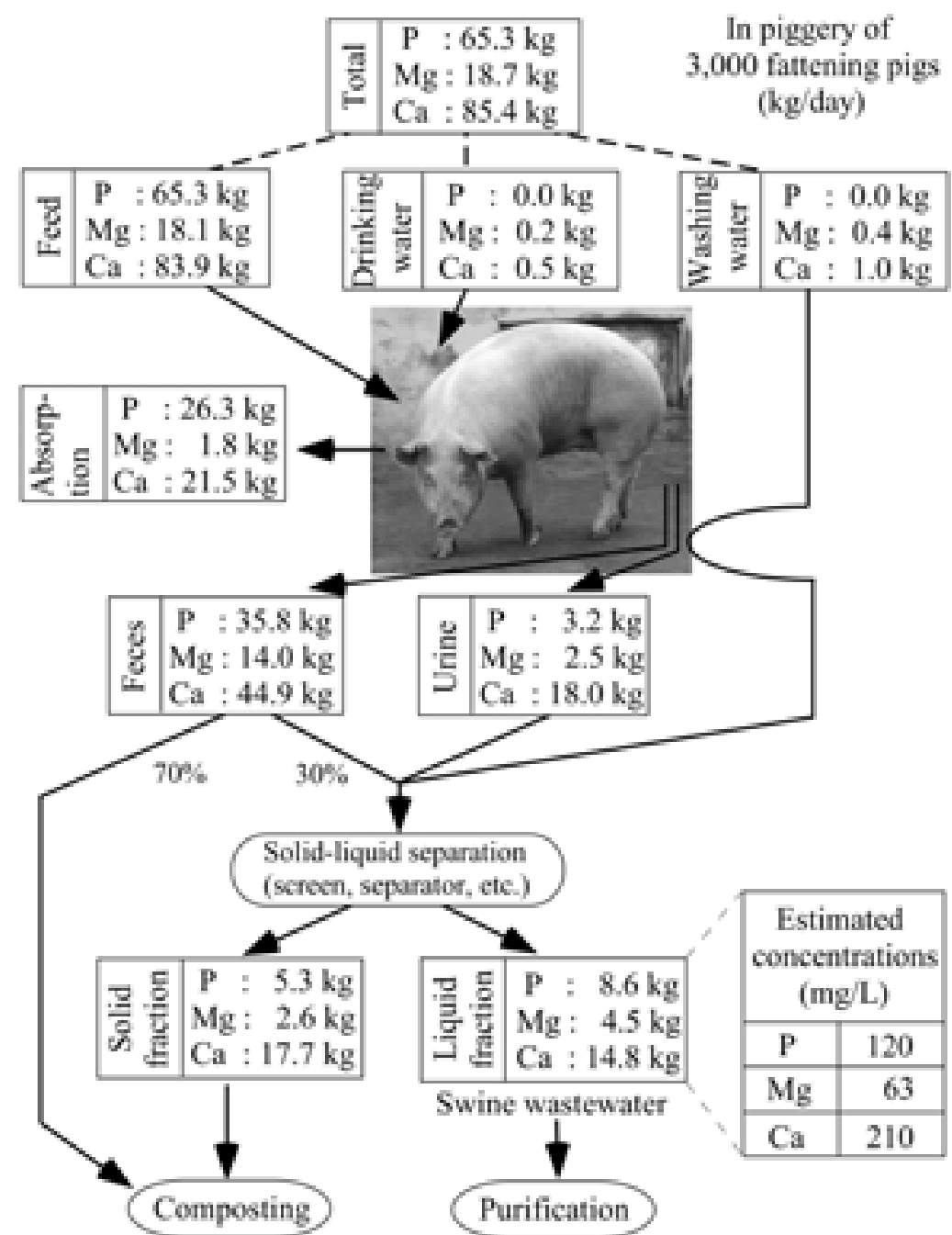

Fig. 2. Estimation of $\mathrm{P}, \mathrm{Mg}$ and $\mathrm{Ca}$ flows in an average swine husbandry system in Japan In this case, $30 \%$ of excreted feces became mixed with urine and washing water. 
soluble components were determined by the method of Suzuki et al. ${ }^{10}$. As shown in Table 1, each sample of swine wastewater contains high concentrations of $\mathrm{P}, \mathrm{Mg}$ and $\mathrm{Ca}$ with $\mathrm{pH}$ variations between 5.7 and 8.7. There was a tendency for much $\mathrm{PO}_{4}-\mathrm{P}, \mathrm{NH}_{4}-\mathrm{N}, \mathrm{Mg}$, and $\mathrm{Ca}$ to exist in soluble form in swine wastewater at a relatively low $\mathrm{pH}$ range (5.7-7.4). Therefore, $\mathrm{PO}_{4}, \mathrm{Mg}$ and $\mathrm{NH}_{4}$ became crystallized, forming struvite (MAP: magnesium ammonium phosphate) when the $\mathrm{pH}$ of swine wastewater rose (Fig. 3). Struvite is known as a valuable slowrelease fertilizer. $\mathrm{Ca}$ also crystallizes with $\mathrm{PO}_{4}$ and forms, for example, hydroxyapatite (HAP) ${ }^{13}$. These phosphate crystallization reactions are accelerated when the $\mathrm{pH}$ of wastewater is between 8 and 9 .

According to our estimation, if $30 \%$ of excreted feces would be mixed with urine and washing water, approximately 10,000 $t$ of phosphorous would be discharged in swine wastewater every year in Japan. This amount corresponds to $7.4 \%$ of the total phosphorous in waste and wastewater $(135,000 \mathrm{t})$, and $1.46 \%$ of the total phosphorous imported $(683,000 \mathrm{t})$ in 1998. Since the Kyushu and Kanto areas of Japan are home to large herds of swine, we also found the total phosphorous amount in swine wastewater to be high in both these areas (Fig. 4), confirming that they have a particularly high potential for phosphorous recovery in Japan ${ }^{13}$.

These properties of swine wastewater lead to problems of scale in wastewater treatment plants, where crystallization reactions occur under natural conditions ${ }^{3}$. Scale accumulating in pipes and pumps sometimes causes serious problems at such treatment plants. However, these properties of swine wastewater and crystallization reactions can also provide the technology for phosphorous removal and recovery when they are made to occur under controlled conditions.

The removal and recovery of phosphorous with crystallization reactions should be conducted during the very first stage of wastewater treatment so as to reduce the concentration of phosphorous to approximately a 50 $\mathrm{mg} / \mathrm{L}$ level, thus minimizing the risk of scaling (Fig. 5).

Table 1. $\mathrm{P}, \mathrm{N}, \mathrm{Mg}$, and Ca concentrations $(\mathrm{mg} / \mathrm{L})$ in swine wastewater from 9 piggeries in Japan

\begin{tabular}{|c|c|c|c|c|c|c|c|c|c|c|}
\hline \multicolumn{2}{|c|}{ Components } & \multicolumn{9}{|c|}{ Swine wastewater from 9 piggeries (a-i) } \\
\hline & & $\mathrm{a}$ & $\mathrm{b}$ & $\mathrm{c}$ & $\mathrm{d}$ & e & $f$ & g & $\mathrm{h}$ & $\mathrm{i}$ \\
\hline \multirow[t]{3}{*}{$P$} & Crystallized $\mathrm{PO}_{4}-\mathrm{P}$ & 25 & 12 & 12 & 22 & 31 & 19 & 208 & 273 & 149 \\
\hline & Soluble $\mathrm{PO}_{4}-\mathrm{P}$ & 112 & 217 & 121 & 161 & 68 & 34 & 158 & 40 & 87 \\
\hline & Total P & 177 & - & 146 & 195 & 102 & 65 & 365 & 316 & 263 \\
\hline \multirow[t]{2}{*}{$\mathrm{N}$} & Soluble $\mathrm{NH}_{4}-\mathrm{N}$ & 90 & 3,780 & 373 & 543 & 779 & 153 & 2,722 & 1,430 & 3,026 \\
\hline & Total N & 497 & 3,947 & 415 & 682 & 852 & 241 & - & 2,055 & 3,745 \\
\hline \multirow[t]{2}{*}{$\mathrm{Mg}$} & Soluble $\mathrm{Mg}$ & 63 & 83 & 68 & 119 & 63 & 46 & 12 & 22 & 5 \\
\hline & Total $\mathrm{Mg}$ & 80 & 97 & 75 & 129 & 66 & 56 & 187 & 226 & 156 \\
\hline \multirow[t]{3}{*}{$\mathrm{Ca}$} & Soluble Ca & 148 & 88 & 156 & 136 & 128 & 84 & 120 & 84 & 64 \\
\hline & Total Ca & 369 & 633 & 200 & 188 & 313 & 172 & 381 & 569 & 224 \\
\hline & $\mathrm{pH}$ & 5.7 & 5.7 & 6.2 & 6.7 & 7.0 & 7.4 & 7.7 & 8.1 & 8.7 \\
\hline
\end{tabular}

\section{Struvite crystallization reaction}

$$
\mathrm{HPO}_{4}{ }^{2-}+\mathrm{NH}_{4}{ }^{+}+\mathrm{Mg}^{2+}+\mathrm{OH}^{-}+6 \mathrm{H}_{2} \mathrm{O} \rightarrow \frac{\mathrm{MgNH}_{4} \mathrm{PO}_{4} \cdot 6 \mathrm{H}_{2} \mathrm{O}}{\text { struvite }} \downarrow+\mathrm{H}_{2} \mathrm{O}
$$

(MAP: magnesium ammonium phosphate)

\section{Hydroxyapatite crystallization reaction}

$$
10 \mathrm{Ca}^{2+}+2 \mathrm{OH}^{-}+6 \mathrm{PO}_{4}^{3-} \rightarrow \frac{\mathrm{Ca}_{10}(\mathrm{OH})_{2}\left(\mathrm{PO}_{4}\right)_{6} \downarrow}{\text { hydroxyapatite }}
$$

(HAP)

Fig. 3. Phosphate crystallization reactions 


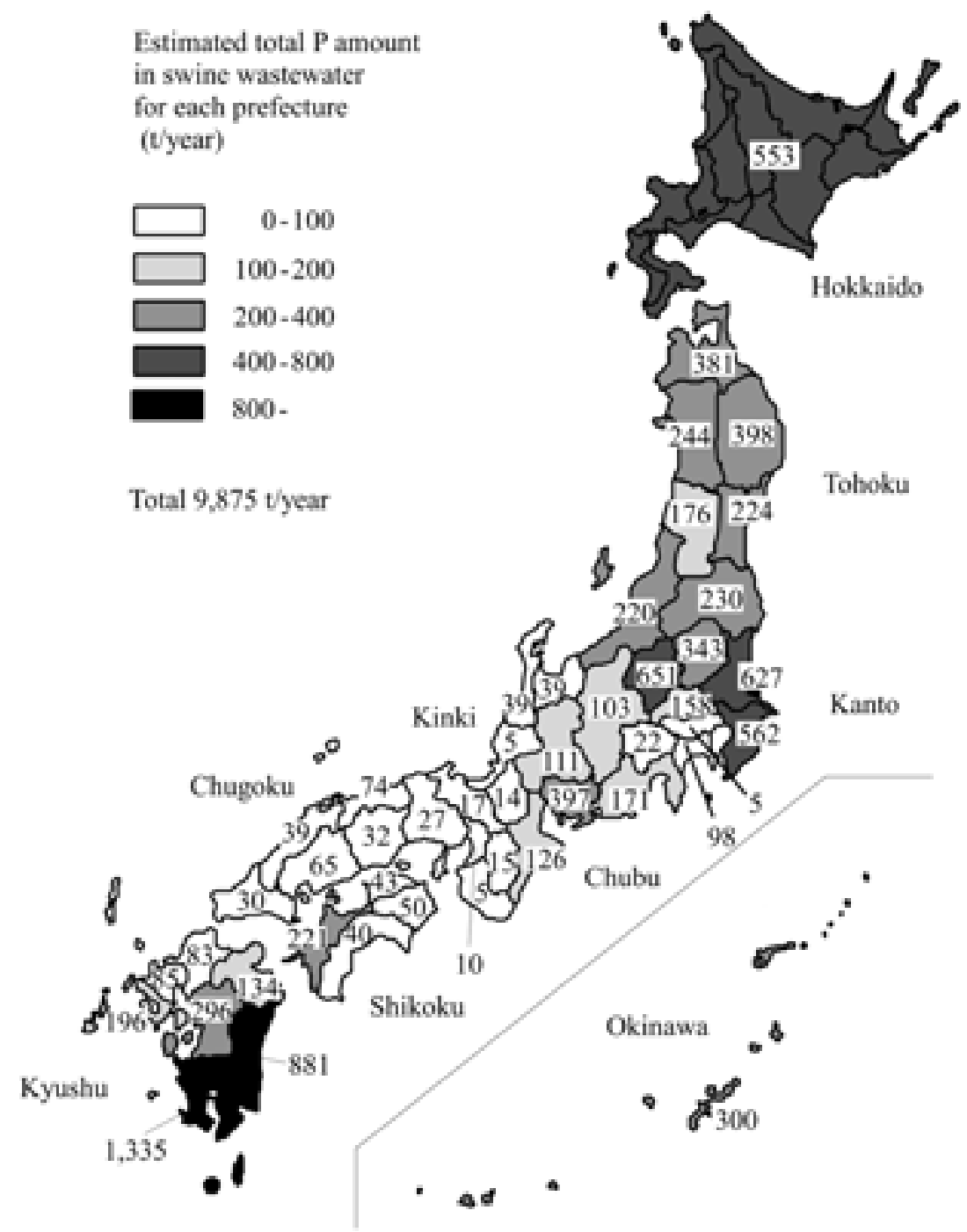

Fig. 4. Estimated total phosphorous amounts in swine wastewater for each prefecture in Japan

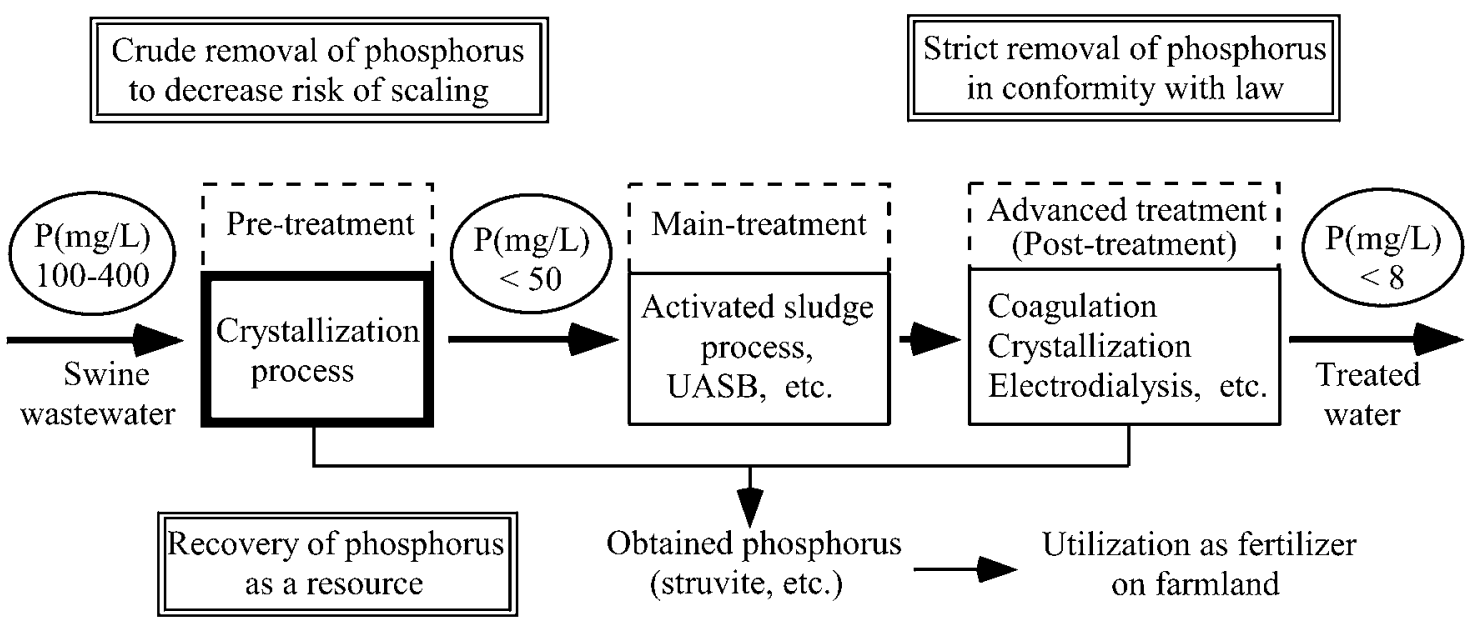

Fig. 5. Proposed procedures for swine wastewater treatment including phosphorous removal and recovery (from the standpoint of phosphorus handling) 
In this case, strict removal (and recovery) of phosphorous is required after the main treatment of swine wastewater mandated by law prior to being discharged into public waters $^{13}$.

\section{Crystallization reactor for struvite formation in swine wastewater}

A reactor for removing and recovering phosphorous from swine wastewater was designed with a dual function i.e., crystallization through aeration, and separation of formed struvite by settling ${ }^{12}$. The $\mathrm{pH}$ of wastewater increases with aeration because of $\mathrm{CO}_{2}$ stripping ${ }^{2,18}$. As shown in Figs. 6A and 6B, by aeration with $0.45 \mathrm{~m}^{3} / \mathrm{h}$, the $\mathrm{pH}$ of swine wastewater increased from 7.0 to 8.0 in $0.5 \mathrm{~h}$, and reached 8.5 at the end of the period. The concentrations of soluble $\mathrm{PO}_{4}-\mathrm{P}, \mathrm{Mg}$ and $\mathrm{Ca}$ in swine wastewater were decreased remarkably with the rise in $\mathrm{pH}$. This decrease was caused by the crystallization of soluble $\mathrm{PO}_{4}-\mathrm{P}, \mathrm{Mg}$ and $\mathrm{Ca}$. Two hours are thought to be enough of an aeration period for crystallization in swine wastewater, because the concentrations of soluble $\mathrm{PO}_{4}-\mathrm{P}, \mathrm{Mg}$ and $\mathrm{Ca}$ in swine wastewater were decreased remarkably for the $2 \mathrm{~h}$ after beginning aeration, but there were only minimal changes in the concentrations of these compo- nents after 2 h. As shown in Fig. 6C, reduced aeration of $0.23 \mathrm{~m}^{3} / \mathrm{h}$ was not enough to either raise $\mathrm{pH}$ or crystallize $\mathrm{PO}_{4}-\mathrm{P}$. On the other hand, aeration as high as $1.11 \mathrm{~m}^{3} / \mathrm{h}$ would induce high $\mathrm{pH}(8.7)$, but the efficiency of $\mathrm{PO}_{4}-\mathrm{P}$ crystallization was almost the same as for the case of aeration with $0.45 \mathrm{~m}^{3} / \mathrm{h}$. Therefore, aeration with $1.11 \mathrm{~m}^{3} / \mathrm{h}$ would be too much for efficient $\mathrm{PO}_{4}-\mathrm{P}$ crystallization ${ }^{12}$.

This reactor, which is incorporated into the first stage of the swine-wastewater treatment process mainly to decrease the risk of scaling, can be adapted with only minor modifications to an existing primary settling tank, thus making it more readily acceptable to swine farmers.

The demonstration reactor (Fig. 7) has been operated continuously for 2 years in National Institute of Livestock and Grassland Science (NILGS: Tsukuba, Japan) using swine wastewater. Oil has been added to decrease foam formation at the aeration column. The equipment for the $\mathrm{MgCl}_{2}$ additive used to increase the efficiency of struvite crystallization is optional. Figure 8 shows the transition of $\mathrm{pH}$ as well as the concentrations of suspended solids (SS) and phosphorous (P) during the 2-year operation of the demonstration reactor ${ }^{13}$.

This reactor is incorporated into the pre-treatment stage of the swine-wastewater treatment process (Fig. 5), and the struvite formed will settle with other organic sus-
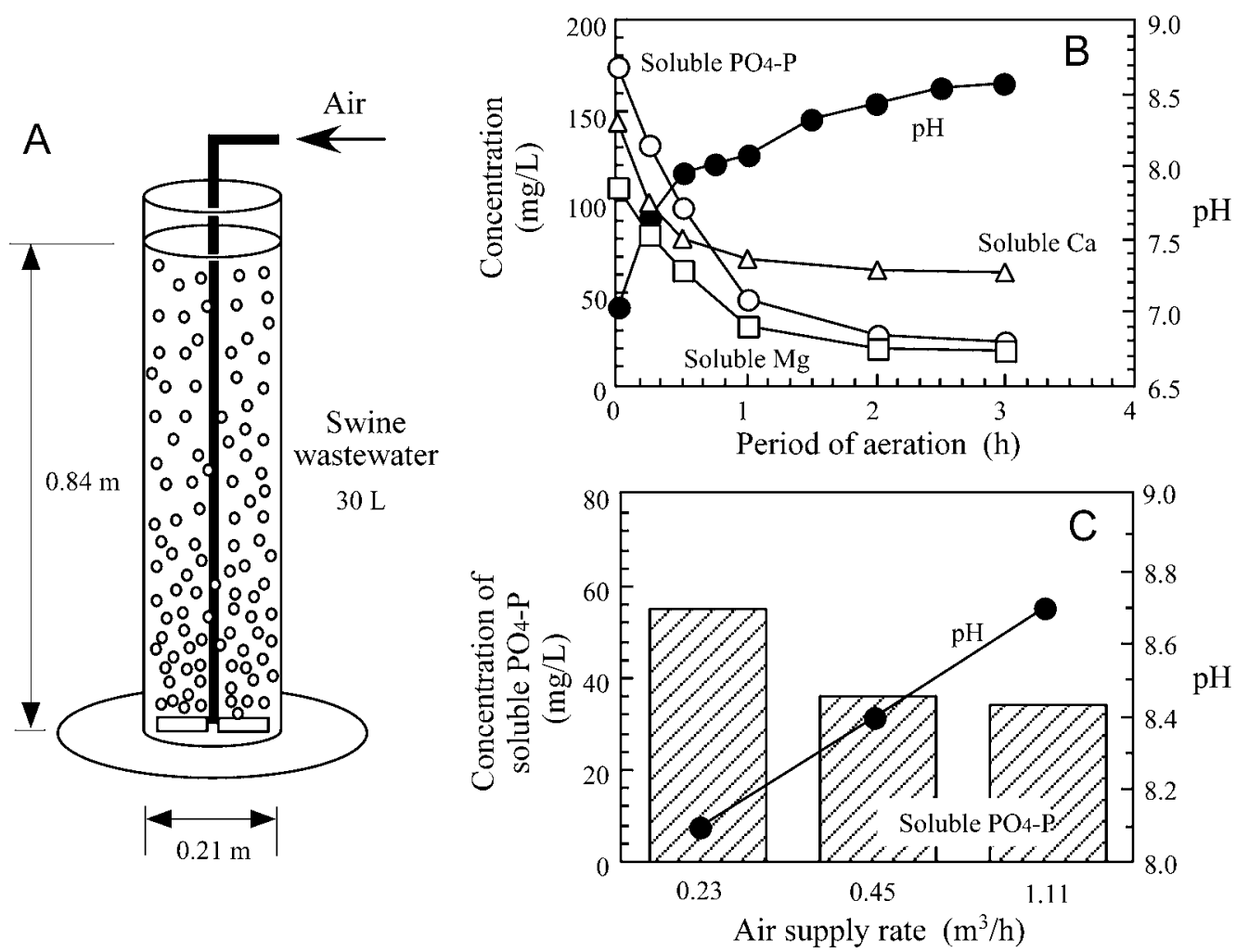

Fig. 6. Batch experiment for crystallization by aeration 

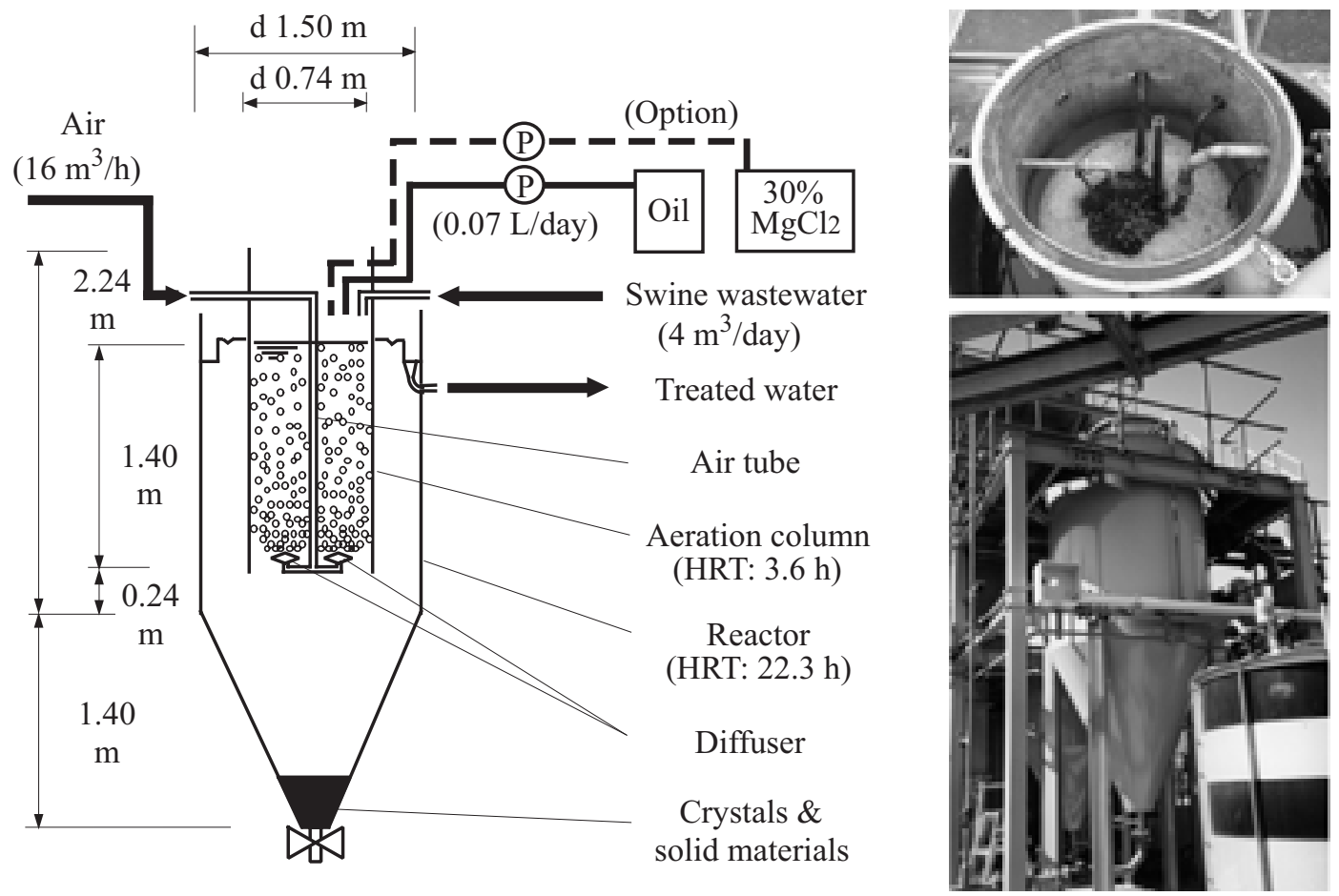

Fig. 7. Layout and photographs of NILGS demonstration crystallization reactor
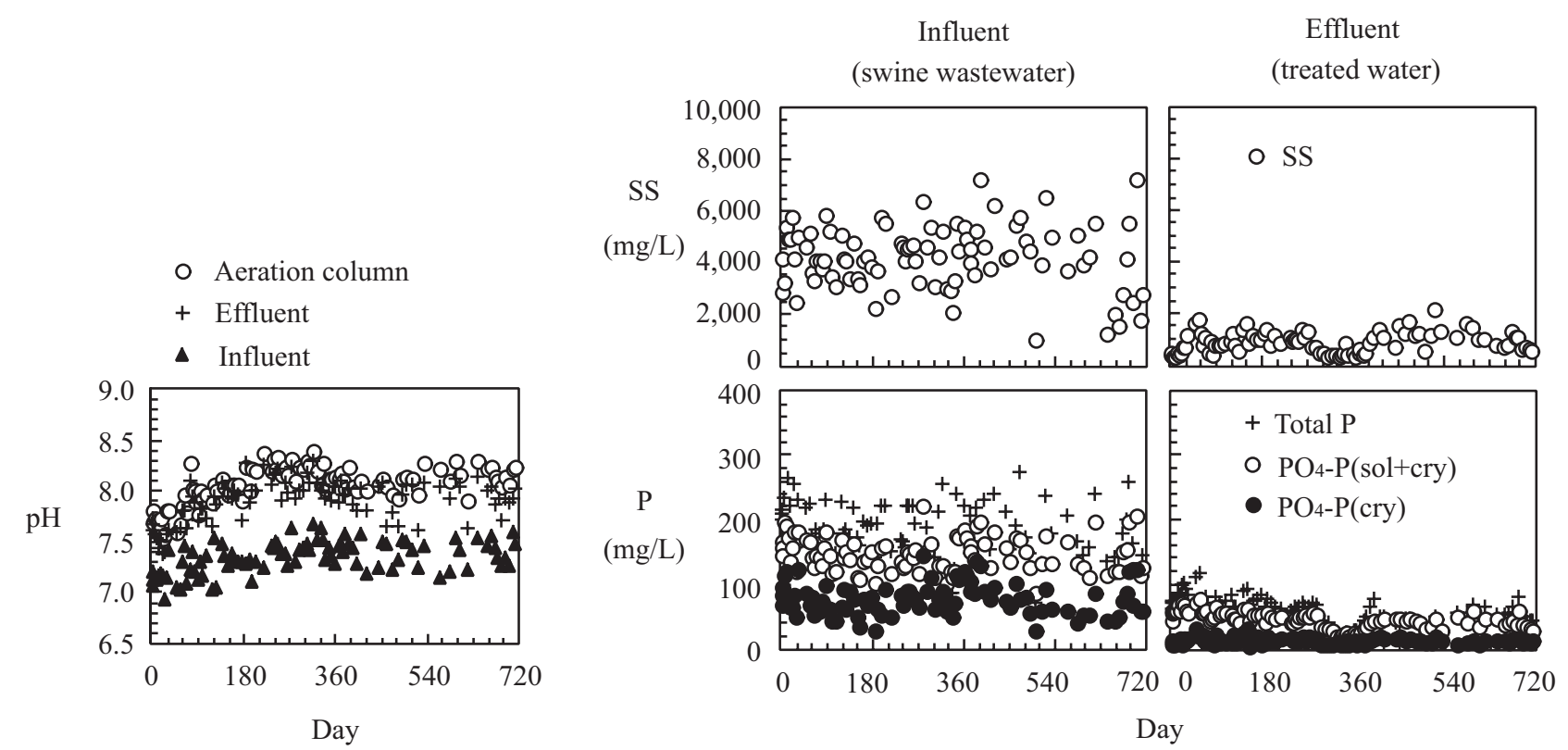

Fig. 8. Transition of parameters during a 2-year operation of demonstration reactor 
Table 2. Chemical characteristics of accumulated crystals

\begin{tabular}{|c|c|c|c|c|c|c|}
\hline \multirow[t]{2}{*}{ Fractions } & \multirow[t]{2}{*}{ Components } & \multicolumn{3}{|c|}{ Accumulated struvite } & \multicolumn{2}{|c|}{ Struvite (theoretical) } \\
\hline & & $\mathrm{mg} / \mathrm{kg}$ & $\mathrm{mg} / \mathrm{kg}$ & mole ratio & $\mathrm{mg} / \mathrm{kg}$ & mole ratio \\
\hline $\begin{array}{l}\text { 1N HCl-insoluble } \\
\text { (Organic matter) }\end{array}$ & & 47,900 & & & & \\
\hline \multirow[t]{9}{*}{$\begin{array}{l}1 \mathrm{~N} \mathrm{HCl} \text {-soluble } \\
\text { (Struvite) }\end{array}$} & & 952,100 & & & & \\
\hline & $\mathrm{PO}_{4}$ & & 366,058 & 1.000 & 388,000 & 1.000 \\
\hline & $\mathrm{NH}_{4}$ & & 73,800 & 1.064 & 73,000 & 1.000 \\
\hline & $\mathrm{Mg}$ & & 96,870 & 1.047 & 98,000 & 1.000 \\
\hline & $\mathrm{Ca}$ & & 167 & 0.001 & 0 & 0.000 \\
\hline & $\mathrm{K}$ & & 1,880 & 0.013 & 0 & 0.000 \\
\hline & $\mathrm{Cu}$ & & 37 & 0.000 & 0 & 0.000 \\
\hline & $\mathrm{Zn}$ & & 69 & 0.000 & 0 & 0.000 \\
\hline & Other $\left(\mathrm{H}_{2} \mathrm{O}\right)$ & & 413,219 & & 441,000 & \\
\hline
\end{tabular}

pended solids. Therefore, a dehydration, composting and characterization process is first needed prior to applying sediment sludge, including struvite, to farmland. If struvite could be recovered as a pure, ready-to-use material, it would be advantageous for immediate application to farmland $^{13}$.

\section{Accumulation of struvite on the surface of submerged material in the reactor aeration column}

In the operation of the demonstration reactor, crystal accumulations were observed on the surface of the air tube and the inside walls of the aeration column. According to chemical analysis, these crystals were confirmed to be struvite, and were almost completely free of organic materials (Table 2). They could then be scraped off easily by merely a light brushing. This presented the possibility of recovering unadulterated struvite for beneficial application to farmland ${ }^{14}$.

In our previous study, we reported that not only struvite, but also hydroxyapatite was formed in the aeration column ${ }^{12}$. Because of the low $\mathrm{Ca}$ concentration in accumulated crystals, the formed hydroxyapatite did not accumulate on the surface of submerged materials in the aeration column, and was thought to settle to the bottom of the reactor with organic materials. Since concentrations of $\mathrm{K}, \mathrm{Cu}$ and $\mathrm{Zn}$ in the accumulated crystals were not all that high, there was little need to be concerned about these minerals when accumulated struvite was used on farmland ${ }^{14}$.

To evaluate the struvite accumulation rates of each material, test specimens (plates) of aluminium, stainless

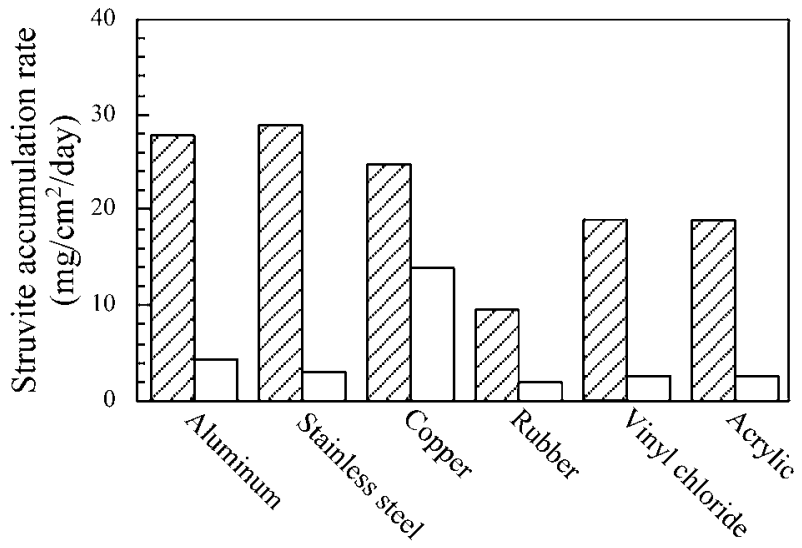

Fig. 9. Struvite accumulation rates on each material

$\square$ : Coarse face, $\square$ : Smooth face.

steel, copper, rubber, polyvinyl chloride, and acrylic were submerged in the aeration column of the demonstration reactor. To test the specimens, both coarse and smooth plates $(10 \mathrm{~cm} \times 10 \mathrm{~cm} \times 0.3-0.5 \mathrm{~cm}$ each $)$ were used, so that the difference in the struvite-accumulation rates between the two plate materials could be reported ${ }^{5}$. These test specimens were fixed to the inside wall of the aeration column, and removed after 34 days' submersion. As shown in Fig. 9, struvite accumulation rates on the coarse plates were higher than those on the smooth plates for every material. Higher struvite accumulation rates were observed on the coarse specimens of aluminium, stainless steel and copper than on those of polyvinyl chloride and acrylic ${ }^{14}$. This same accumulation tendency was also reported by Ohlinger et al. ${ }^{8}$. 

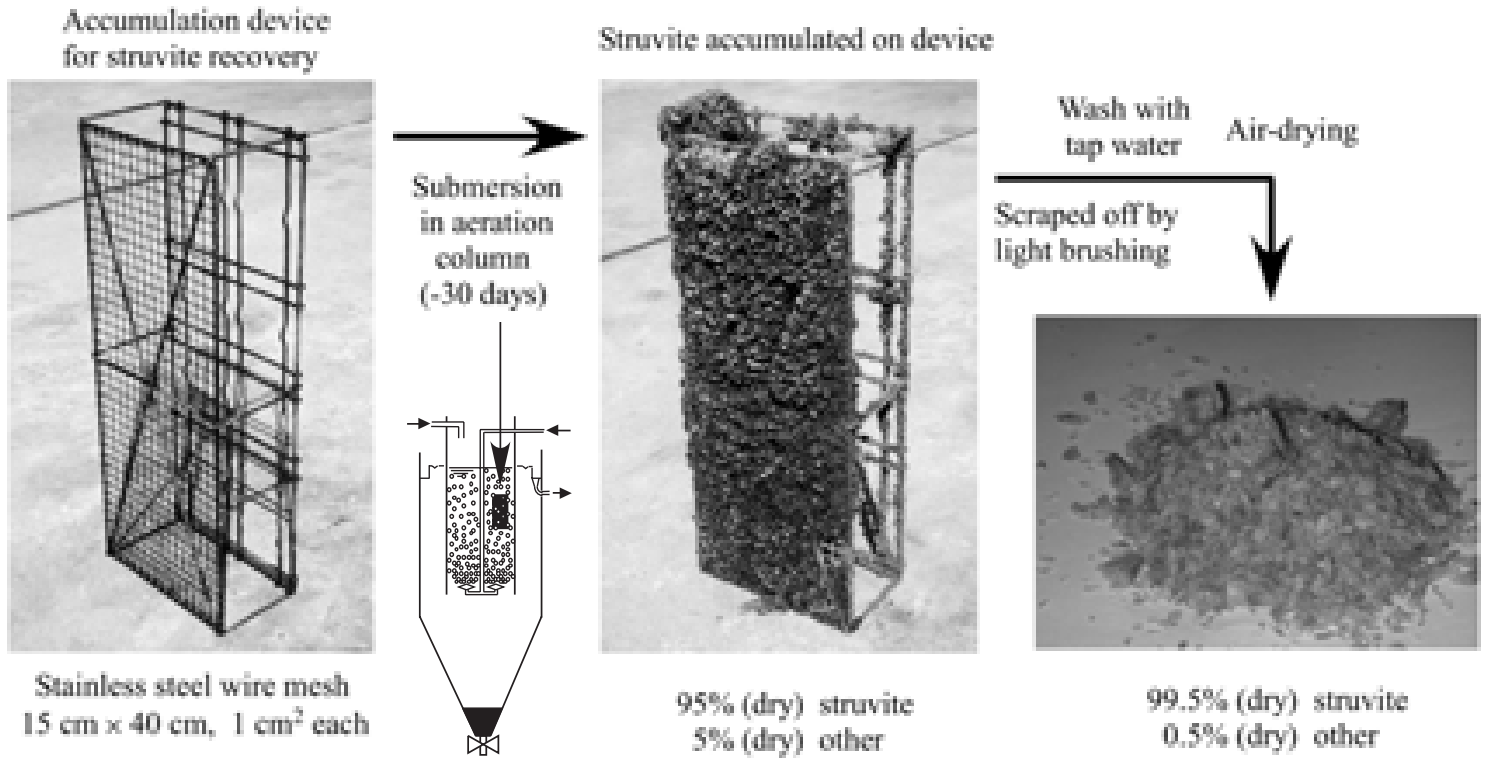

Fig. 10. Struvite recovery with experimental accumulation device

\section{Accumulation device for struvite recovery}

For the recovery of pure struvite, a customized accumulation device was designed and its efficiency examined. The experimental device has a struvite-accumulation face $(15 \times 40 \mathrm{~cm})$ made of stainless steel wire mesh (1 $\mathrm{mm}$ diameter wire; $1 \mathrm{~cm}^{2}$ mesh) to reduce the total weight of the device.

During the 30-day submersion in the aeration column of the demonstration reactor, $1,037 \mathrm{~g}$ of struvite cross-bridged on the struvite accumulation face (Fig. 10). The struvite could be scraped off easily with only a light brushing. The purity of that struvite was $95 \%$, and it was increased to $99.5 \%$ by washing with tap water before airdrying. The recovered struvite needs only air-drying, but no dehydration, composting or characterization before use since it is approximately $95 \%$ pure even without washing. Therefore, it is ready for immediate application to farmland ${ }^{14}$. Experiments with a demonstration struvite-recovery device are ongoing in NILGS.

\section{Conclusion}

According to our estimation, approximately $10,000 \mathrm{t}$ of phosphorous are annually discharged in swine wastewater, establishing its high potential for phosphorous recovery in our country. A reactor for removing and recovering phosphorous from swine wastewater was designed with the dual functions of crystallization through aeration, and of separation of formed struvite by settling. However, a dehydration, composting and characterization process is first needed before applying sediment sludge, including struvite, directly to farmland. For the recovery of pure struvite, a specialized accumulation device was designed and its efficiency examined. During submersion in the aeration column of the demonstration reactor, 95\%-pure struvite cross-bridged to the device's accumulation face, and could be scraped off easily with only a light brushing. Since this device (stainless steel wire mesh) has a very simple structure, it should be readily acceptable to swine farmers. Recovered struvite can be used as a valuable slow-release fertilizer.

This phosphorous (P) handling technology including the suspended solids (SS) reduction effect is incorporated into the pre-treatment stage of the swine-wastewater treatment process, and can be combined with anaerobic and aerobic biochemical oxygen demand (BOD) reducing technologies such as intermittent aeration activated sludge technology ${ }^{9}$ or UASB plus trickling filtration technology ${ }^{15,16}$ at the main treatment stage, it also can be combined with nitrogen $(\mathrm{N})$ reducing technologies such as sulfur utilizing denitrification technology ${ }^{7}$ or methane utilizing denitrification technology ${ }^{17}$ at the post-treatment (advanced-treatment) stage. The concentrations of the main environmental pollution materials such as BOD, SS, $\mathrm{P}$, and $\mathrm{N}$ in swine wastewater can be reduced by sequential combination of these treatment technologies for discharging into public water bodies. 


\section{References}

1. APHA (1992) Standard methods for the examination of water and wastewater 18th edition. American Public Health Association, Washington, DC, USA, pp.1150.

2. Battistoni, P. et al. (1997) Phosphate removal in anaerobic liquors by struvite crystallization without addition of chemicals: preliminary results. Water Res., 31 (11), 2925-2929.

3. Booram, C. V., Smith, R. J. \& Hazen, T. E. (1975) Crystalline phosphate precipitation from anaerobic animal waste treatment lagoon liquors. Trans. ASAE, 18 (2), 340-343.

4. Borgerding, J. (1972) Phosphate deposits in digestion systems. J. / Water Pollut. Control Fed., 44 (5), 813-819.

5. Doyle, J. D. et al. (2002) Struvite formation and the fouling propensity of different materials. Water Res., 36 (16), 3971-3978.

6. Haga, K. (1998) Animal waste problems and their solution from the technological point of view in Japan. $J A R Q, 32$ (3), 203-210.

7. Jin, C. \& Tanaka, Y. (2001) Decoloration and nitrogen removal of swine wastewater after anaerobic treatment using the sulfur filling up reactor. Jpn. J. Water Treat. Biol., 37 (3), 93-98 [In Japanese with English summary].

8. Ohlinger, K. N., Young, T. M. \& Schroeder, E. D. (1999) Kinetics effects on preferential struvite accumulation in wastewater. J. Environ. Eng., 125 (8), 730-737.

9. Osada, T., Haga, K. \& Harada, Y. (1991) Removal of nitrogen and phosphorus from swine wastewater by the activated sludge units with the intermittent aeration process. Water Res., 25 (11), 1377-1388.

10. Suzuki, K. et al. (2001) Concentrations of phosphorous, magnesium and calcium in swine wastewater and possi- bility of removing these components through crystallization. Anim. Sci. J., 72 (1), 72-79.

11. Suzuki, K., Watanabe, T. \& Lam, V. (2001) Concentrations and crystallization of phosphate, ammonium and minerals in the effluents of bio-gas digesters in the Mekong Delta, Vietnam. JARQ, 35 (4), 271-276.

12. Suzuki, K. et al. (2002) Removal of phosphate, magnesium and calcium from swine wastewater through crystallization enhanced by aeration. Water Res., 36 (12), 29912998.

13. Suzuki, K. et al. (2004) Phosphorous in swine wastewater and its recovery as struvite in Japan. In International conference on struvite: Its role in phosphorus recovery and reuse, Cranfield University, Cranfield, United Kingdom, 51-60.

14. Suzuki, K. et al. (2005) Recovery of phosphorous from swine wastewater through crystallization. Bioresource Technol., 96 (14), 1544-1550.

15. Tanaka, Y. (2002) A dual purpose packed-bed reactor for biogas scrubbing and methane-dependent water quality improvement applying to a wastewater treatment system consisting of UASB reactor and trickling filter. Bioresource Technol., 84 (1), 21-28.

16. Tanaka, Y. \& Suzuki, K. (2004) New technology for swine wastewater treatment. Farming Jpn., 38 (1), 1016.

17. Waki, M. et al. (2005) Methane-dependent denitrification by a semi-partitioned reactor supplied separately with methane and oxygen. Bioresource Technol., 96 (8), 921927.

18. Waki, N., Kondou, H. \& Nishida, S. (1987) Phosphate removal from anaerobic digestive effluent by aeration. $J$. Water \& Waste, 29 (7), 636-640. [In Japanese]. 